\title{
Albanian Refugees in Italy
}

\author{
Giovanna Campani
}

In March 1991 the Albanian exodus to Italy involved over 20,000 refugees, who arrived in precarious and rotten boats. They waited in the rain and wind in the bay of Brindisi to be allowed to stay, but the Italian government was cynically indifferent to them.

In August 1991 desperate Albanians jumpedinto the sea from a crowdedship, the Valona, as it came into Bari harbour. But this time, the Italian government's reaction, which may have been condoned by other European states, went far beyond indifference. These people were all sent back. Since then the Adriatic Sea, which divides Albania from Italy, is guarded day and night. As Ruotolo (1992) said, "the sea as a place of freedom or transit towards freedom has become inaccessible for Albanians."

Italian patrol vessels, military ships and coastguards try to prevent any flight. Albanian harbours are watched by soldiers. Still, illegal immigrants manage to reach Italy, as on July 7 when a boat with 109 men, women and children on board tried to force its way into Italian waters. All of them were sent back.

It seems paradoxical that when the Albanian government wants to join the Western democratic world, the latter requests that Albanian citizens be restricted inside the country and even shot if they attempt to get out. Albanians have obtained the right to vote, but they have not obtained the right to leave their country or to travel. Albania is stilla huge jail, as it was at the time of Enver Hodja.

\section{Reasons for the Flight}

In no other Eastern European country has the end of Communist dictatorship been accompanied by such large-scale emigration. There are different reasons for it: economic disaster, fear of civil war

Giovanna Campani teaches at the Universite degl Studi di Firenze, Florence, Italy and lack of confidence in the democratization process and in those who were supposed to promote it. ${ }^{1}$ It is also possible that this mass migration is the Albanian government's manoeuvre to pressure the West, and particularly Italy, into giving them more help.

But apart from these reasons, this exodus can be seen as an explosion of claustrophobia (Colafato 1992) in people who were confined within a small country for forty years. These people do not wish to wait any longer for change in

\section{It seems paradoxical that when the Albanian government wants to join the Western democratic world, the latter requests that Albanian citizens be restricted inside the country and even shot if they attempt to get out.}

Albania. It is certainly difficult to generalize, but refugees' statements to journalists at the time of their arrival and comments made during the indepth interviews we conducted, ${ }^{2}$ express this sense of claustrophobia and wish to enjoy a way of life known only through Italian television. ${ }^{3}$ We did not encounter the will to fight for change in Albania and to construct a new country during any of the interviews conducted between - November and December 1991. Only in some very recent interviews conducted in May 1992 was the will to go back to Albania expressed.

Albania's recent history partly explains these attitudes. This country seems to be suspended in time (Ferraris 1991). It was isolated from the rest of the world by Enver Hodja's dream of

creating a purely autarchical socialist country. Enver Hodja, who was the hero of the Resistance against the Germans and Italians, as well as the leader of the Party of Work (the name of the Communist Party in Albania), broke relations with Tito and turned to Stalin. Later he refused to "de-Stalinize," and took the China's side against the Russians. China was Albania's main partner until 1978 when it stopped providing military and economic aid because of ideological and political conflicts. Albania was always portrayed as the "bright spot" of world socialism in official propaganda. One refugee interviewed in the study commented:

\begin{abstract}
I thought that Yugoslavia was not a Communist country any more. They told us that it was Communist until 1948, then it changed its way because it was no longer in agreement with Enver Hodja. Until 1960 we were friends with Russia, then they told us that Russia had also changed its way. Hodja was friends with China. Then when Mao died, that finished too. And they told us that we were the only bright spot.
\end{abstract}

This change of ideological and trade partners had a devastating effect on the country's already weak economy. ${ }^{4}$ The results were outdated industries and technology, poor agriculture, hard working conditions, no contacts with the rest of the world and widespread poverty. The government's attempt to remain ideologically pure did not succeed either. Despite the propaganda, young people were sceptical of socialist principles and would rather have consumer goods.

The regime's crisis began after Enver Hodja's death on April 11, 1985, but it only became evident five years later. In 1985 Ramiz Alia became the new Secretary of the Party of Work and began modest liberalization, a kind of "Albanian Spring," following the

Refuge, Vol. 12, No. 4 (October 1992) 
examples of other East European countries and especially that of Gorbachev's perestroika, but this relative liberalization resulted in an economic crisis, and living conditions began to get worse.

In July 1990 approximately 5,000 people occupied different European embassies in Tirana. Thanks to international intervention, 4,500 Albanians arrived in Brindisi on July 13. They were brought from Tirana to Dürres. Most of them will not stay in Italy. They will go to Germany, which agreed to take them. It was the only

exodus are also very complex. There was a rumour that there were boats in Albanian harbours to take peopletoltaly. The same rumours sparked the exodus in August 1991 and the most recent one of 10,000 people who wanted to leave the Albanian harbour of Dürres on July 7 and 8, 1992.

How can these rumours be explained? Were they manufactured by the government to push people out of the country and to show the world the extent of Albania's misery? Were there information networks to link those who wanted toleave withowners of boats? Or

\section{Although Albanian refugees are beginning to realize that the myth of Italy does not correspond to reality, they have nowhere else to go. Italy is the closest European country and a gate to Europe, both in a metaphoric and geographic sense.}

"planned" exodus and the only time when Albanians were received and consequently treated as political refugees in Italy. After the "crisis of the embassies," the exodus continued slowly. People leave individually or in small groups, sometimes by boat or plane. Itisstill possible to get tourist visas in some European embassies. It is easier to get an Italian visa than a French or a German one, even though it is necessary to wait for a few months. It is quite difficult but not impossible to obtain a passport, especially for those who are not well-known dissidents, or for those who pay bribes or have friends in the ministries or in the Party.

By March 1991 the economic situation continued to deteriorate and there wasstill much political uncertainty. On December 1, 1990 Ramiz Alia promised free elections on February 10, 1991. On December 12, the Democratic Party was founded. But on January 16, 1992 Ramiz Alia rescheduled the elections for the end of March, and on February 20 he formed a new government.

The March exodus was a response to the uncertainty and insecurity within the country a few weeks before the elections. However, the dynamics of the wasitan explosion of claustrophobia that occurred when it seemed possible that a dream might become reality for people who lost hope for the future?

Regardless of the origin of the rumours, they prompted people to rush to the harbours without taking any of their possessions. They squeezed in the boats. People who lived in the ports of Dürres and Valona had a better chance of getting on the boats first. From the northern town of Dürres boats went to Valona and left for Brindisi and Otranto. Most Albanian immigrants in Italy are from Dürres and Valona.

Protests against the government are the strongest in urban areas. Rural Albania is still supportive of the Party of Work. Ramiz Alia and the Party of Work will win in the elections, thanks to rural voters.

Because of the Italian government's negligence, Albanians met bad conditions in Brindisi during their first few days, but the government's response was compensated for by the generous attitude of the Italian people, or at least of thoselivingin Brindisiand Otranto. Most of the Albanians whom we and some journalistsinterviewed felt grateful to the people of Brindisi and Otranto. Only a few complained of exploitation.
In March 1991 the Italian government received 26,000 refugees and found them places to stay. Only one boat went back to Albania. Although Albanian refugees are beginning to realize that the myth of Italy does not correspond to reality, they havenowhere else to go. Italy is the closest European country and a gate to Europe, both in a metaphoric and geographic sense. As one refugee said, "I would have liked to go to Germany, but I could not get a visa-the embassy was always closed. There was no choice but to emigrate to Italy or to Greece. I wanted to go to Germany. I was in Austria to study and I speak the language."

So the exodus continued between March and August 1991. Most of the rafts were stopped and people were sent back-often in a harsh way-after an exhausting trip (D'Angelis 1992). In August 1991 there was another mass exodus. This time, the myth of Italy was definitely shattered. Albanians understood that they could be sent back in the most humiliating way. Still, there were new attempts to leave in July 1992. As one refugee explained, "There is nothing to do in Albania, at least for twentyyears." "How many years will go by before Albania becomes rich, democratic and prosperous? We will be old and Europe will always be better," said another Albanian refugee. Western aid is not sufficient. It is just enough to enable the country to survive. The victory of SaliBerisha's Democratic Party has not performed any miracles. The West did not give any more aid just because the Democratic Party won the election.

\section{Attitudes of the Italian Govern- ment and the Italian Population to the Albanian Exodus}

If in March the Italian government adopted a cynical and neglectful attitude, in August it used a "mixture of force and astuteness" (Rusconi 1991) to send back the Albanians, which provoked shame among the Italians. Paolo Giuntella (1991) wrote, "It is one of the most shameful pages of our recent history." No real effort was made to communicate 
with the Albanians or to analyse Italian public opinion. In fact, the media expressed hardly any opposition to receiving the refugees. Only one newspaper, Il Manifesto, suggested that perhaps receiving 20,000 or even 40,000 people was not so dramatic, considering what other countries had done (Germany with East Germans and Turkey and Iran with Kurds). For the rest of the press, it was more or less clear that the arrival of so many people would provoke crises in social services, the labour market and everyday life.

In February 1990 Law 39 (known as the Martelli Law), which sets new procedures for immigration, was adopted. One generous provision of this law allowed 223,000 illegal immigrants, mainly from Third World countries, to obtain residence and work permits. The law also established procedures for regulatingimmigration in the future. The immigrant intake for 1991 was set atzero.

The mass arrival of Albanians forced the government to review this plan, and in March Albanians received temporary permits that were valid until July 15 , 1991. If they found jobs or vocational training courses by then, the permits would become permanent in agreement with the provisions of the Martelli Law.

In April the Italian government established a new Ministry of Emigration and Immigration, headed by Margherita Boniver, a socialist deputy. On May 11, Margherita Boniver was also designated an "Extraordinary Commissary for the Albanian Emergency," replacing the former Minister for Civil Protection.

In early March, it was decided to disperse Albanians throughout the country instead of keeping them in Puglia. In May there were still over 9,000 Albanians in the Puglia, so Margherita Boniver had to accelerate their resettlement in other regions. The attitudes of local authorities in these regions varied. Some were generous and did everything to find lodging and work for Albanians, while others refused to take them.

Albanians lived under the threat of expulsion. Eventually, their temporary status was extended to July 31 and finally to March 1992, but fear of being sent back

will push many Albanians to become illegal immigrants in order to avoid restrictions.

At the end of October 1991, Margherita Boniver announced that among 24,157 Albanians, 645 obtained political refugee status $(17,718$ had solicited it); 2,715 were sent back; 315 were expelled; 9,452 found jobs; 711 found vocational training courses; and approximately 8,000 had not yet found jobs. The rest became illegal immigrants. Although the Minister of Emigration and

\section{"It is so close! We would go for a weekend and come back and work here. But if we go, we cannot get out."}

Immigration was pleased with the results, she did not wish to accept more Albanians. In fact, she approved of the treatment Albanians received in August and contended:

\begin{abstract}
"We were able to respond quickly to the dramatic events of last August. In the meantime, political conditions in Albania changed as a democratic government was formed, which gave an opportunity to all the main political forces to participate. By repatriating 17,476 Albanians from August 8-13, and another 3,400 (including 700 soldiers) on August 17, we were able to show respect to Law 39/90" (Boniver 1991).
\end{abstract}

What Boniver refers to as "respect to Law 39/90" translated into terrible images of Albanians trapped in a stadium and being thrown sandwiches, as if they were animals. Many were taken away in the middle of the night. They included children who found Italian families ready to take them. Shameful as these memories are to many Italians, nevertheless even the public failed to show as much hospitality to the Albanians in August as they did in March.

Colafato (1991) explains this difference by relating the Albanians' arrival in March to the Gulf War. After the trauma of a horrible war, the public expressed an "after-war solidarity." In
August, the situation was different. The impending war in Yugoslavia produced much anxiety, since it promised to provoke mass flights. Furthermore, difficulties created by the first exodus reduced solidarity to a minimum. Still, Colafato (1991) insists, present sociocultural processes in Italian society leave room for attitudes of solidarity, but tend much more towards defending individual welfare and particular interests.

\section{A Sea and a Prison}

"I left Albania for personal reasons. I like the Communist theory-no rich, no poor-I like it, but I didn't like my town. I wanted to see the world and to cross the sea," said a young Albanian from Dürres, who arrived in Italy in March 1991 and who is now living in Portocannone, Molise, a small Italian-Albanian village. His case is certainly exceptional: in our thirty-four interviews, he is the only one whoconsiders himself a Communistand is favourable to Communist theory. Still, his case is interesting: he wanted to travel, to see the world, to cross the sea he had seen since his childhood. Todo so, he had to get in a crowded boat, risk his life at sea and be humiliated by the Italian government. Other refugees told us that they would go back to Albania every month if they could. "It is so close! We would go for a weekend and come back and work here. But if we go, we cannot get out."

On September 4, 1991, the Italian government, in agreement with the Albanian government, decided to create the XXII Navy Group to prevent another mass exodus. Two coastguard patrol vessels (vedettes) stay in Dürres harbour. There is also an Italian ship and Italian headquarters. One hundred Italian soldiers watch the Albanian Sea. The XXII Navy Group works with Albanian ships. Since August, the Albanian authorities have required ships to anchor in roadstead to prevent exodus. The Italian vedettes patrol $300 \mathrm{~km}$ of the Albanian coastline. The Albanian soldiers control the harbours. On July 7, 1992 10,000 Albanians protested against this tight control and were shot at by the soldiers. 


\section{Albanians In Italy}

In general, the present situation of the 24,000 Albanians in Italy is no longer as desperate as it was earlier. Many of them found work in agriculture in the South. In Central and NorthernItaly, they found work in construction, small factories and janitorial services. Local authorities, despite the negative attitudes of some, assisted Albaniansinfinding work. They found warm reception in ItalianAlbanian villages. The fact that Albania is so close could make travel to and from Italy easy if there were no barriers. Migrants could play an important role in the development of Albania. Seasonal migration could be a solution for some people. The Albanian immigrants interviewed last May were critical of the violence and drug problems in Italy. They lamented for a more simple life. Some were thinking of going back.

Let's hope that in the not-too-distant future the Adriatic Sea will become a place of exchange, crossed not by vedettes and military ships or by rafts of desperate people, but by boats of people at home on both sides of the water.

\section{Notes}

1. Some people in the present government, like Ramiz Alia, used to be in Enver Hodja's government.

2. In October 1991 I began research on eastern immigration in Italy. The goal was to conduct about fifty qualitative interviews in Tuscany, Liguria and Emilia-Romagna. I hoped to conduct return interviews with some people to see how they integrated. Unfortunately, it was possible to interview only twentyfive people, twelve of whom were Albanians. In May we interviewed other refugees, includingsix Albanians. All the Albanians were living in Tuscany (Florence, Signa, Scandicce). At the same time, a student from my department did research on the Albanians in Portocannone, a small village in the Molise, founded by Albanian refugees of Skanderberg in the fifteenth century. The student conducted sixteen interviews. Although our methodologies were different, we were still able to compare results. In the article I referred to thirtyfour interviews, and I also made use of press releases.
3. The importance of Italian television in creating the Italian myth in Albania has beenemphasized by many observers and journalists. Albanian refugees referred to Italian television when they explained how they gained knowledge of Italy. It was not by chance that in March 1991 the director of an Italian channel felt it was his duty to explain to Albanians that Italian reality is not the one that appeared on television.

4. The level of development is not comparable to that of other former socialist countries. In Albania 50 percent of the population worked in agriculture in 1988, 66 percent were rural. In Romania it was 22 percent and 49 percent, respectively; in Poland 22 percent and 39 percent; in Bulgaria 14 percent and 34 percent (De Agostini 1991). Albanian cities are quite small. Tiranancounts, the capital, has only 225,000 inhabitants; Dürres 80,000 and Valona 70,000 (De Agostini 1991). The total population in Albania is approximately three million people.

\section{References}

Boniver, M. “Relazione sull' attuazione delle norme urgenti in manteria di asilo politico, di ingresso e soggiorno di cittadini exra-comunutari e di regolarizzazione dei cittadini extracomuniatri e apolidi già presenti nel territori nazionale." In Vita Italiana Speciale (5/1991):7-40.

Campani, G. "L'immigration en provenance des pays de l'Est vers l'Italie. Le cas de l'immigration albanaise." In Hommes et Migrations (Juin 1992).

Colafato, M. "Le onde albanesi e la riva italiana." In Il Mulino, no. 6 (NovemberDecember 1991):1072-1081.

De Agostini. Guide geografice, Novara, 1991.

D'Angelis, E. “Fuggire dall'Albania. Diario di Sconfitti." In L'impero del mare, Il Manifesto del mese, no. 5 (1992):24-25.

Ferraris, S. "L'altra sponda del mare." In Arancia Blu (April 1991):7-11.

Girntella, P. "Italiani Braba gente." In Senzaconfine, nos. 68, 69, 70, 71, 72 (1991).

Ruotolo, G. "Zattere di speranza per gli Albanesi." In L'impero del mare (1992):23.

Rusconi, G.E. Introduzione of conregno, Immigrazione in Europe impatco culturale e probelem ol'cittasliusune. Rome: Goethe Institut, 3-4/12/1992.
CENTRE FOR REFUGEE STUDIES

York University

Research, Conterence and Travel erants

CRS grants are intended to assist and encourage research on "refugeeand development" - ways of understanding and resolving refugee problems in developing countries, This indudes support for research activities on the following topics:

- Refugee settlement in less developed countries

- Repatriation and development in less developed countries

- Forces affecting refugee generation in less developed countries:

- Global changes and policies in sending and receiving countries as well as activities of international agencies that will affect refugee generation and developitent effoits.

Applicationsare considered twice a year. Completed applications must be received by November 15 and March 15 for funding decisions by January 15 and May 15 respectively.

For further details, please contact:

Professor Lary Lam

Centre for Refugee Studies

Suite 317, York Lanes

York University

4700 Keele Street, North York

Ontario, Canada M3J $1 \mathrm{P3}$

Tel: (416) $736-5663$

Fax: (416) 736-5837

E-mail via BITNET, address:

REFUGE@YORKVMI 